\title{
TOMEŠ, I. Vzpomínky na 60 let v oboru sociální politiky, správy a práva.
}

Praha: Univerzita Karlova, Nakladatelství Karolinum, 2019, 210 s.

Příběh v pozadí některých knih by sám stál za písemné zaznamenání, stávalo se to patrně zejména v minulosti a častěji u beletrie, přesto i zde recenzovaná kniha je spojena s historií, jež stojí za osvětlení. Životní osudy právníka a univerzitního profesora Igora Tomeše byly bez diskuze velmi barvité a pozoruhodné, během svého profesního působení se podílel jako expert na reformách systémů sociální ochrany v řadě zemí. Není divu, že ho jeho kolegové a kolegyně i studující nabádali k tomu, aby své paměti sepsal. Neučinil tak, tedy alespoň podle povědomí všech zúčastněných. Teprve v roce 2018 , kdy zemřel v úctyhodném věku 86 let, byly v jeho pozůstalosti nalezeny tyto vzpomínky na 60 let v oboru sociální politiky, správy a práva, jak zní i název knihy. Dvě bývalé žákyně Igora Tomeše, Kristina Koldinská a Kateřina Šámalová, které mezi jinými rozvíjejí jeho odkaz na půdě Univerzity Karlovy, v roce 2019 celý text připravily k vydání. Jak samy v předmluvě uvádějí, jejich zásahy do textu byly zcela minimální proto, aby byl zachován v původní autentické podobě.

Dříve, než se zaměříme na knihu samotnou, stojí za připomenutí základní biografické údaje o osobě prof. JUDr. Igora Tomeše, CSc. (1931-2018). Vystudoval Právnickou fakultu Univerzity Karlovy v Praze, kde brzy po absolutoriu začal působit i pedagogicky a jako první zde přednášel ucelený kurz práva sociálního zabezpečení (od roku 1955). Několik let působil v Ženevě v Mezinárodním úřadu práce, poté se habilitoval pro obor pracovního práva a práva sociálního zabezpečení. Editoval také první učebnici práva sociálního zabezpečení v ČSSR (1968). Po srpnových událostech roku 1968 musel opustit akademickou půdu a pracoval dlouhá léta v hutním průmyslu jako sociální pracovník, sociolog a vědecký pracovník. V roce 1990 byl rehabilitován a jmenován profesorem. V letech 1989-1991 byl prvním náměstkem ministerstva práce a sociálních věcí a podílel se aktivně na reformě systému sociálního zabezpečení (ochrany) v ČR. Jako konzultant Světové banky a EU se podílel na reformách sociálních a zdravotnických systémů v Albánii, Arménii, Bělorusku, Bosně a Hercegovině, Bulharsku, Gruzii, Chorvatsku, Íránu, Kazachstánu, Litvě, Lotyšsku, Makedonii, Moldávii, Polsku, Rusku, Slovensku, Slovinsku, Súdánu a Uzbekistánu. Po odchodu do důchodu se podílel na založení katedry sociální práce na Filozofické fakultě UK, kde až do své smrti působil. Napsal na 300 odborných článků a přednášel na řadě zahraničních univerzit a mezinárodních konferencí, publikoval celkem 17 knih. Tolik tedy stručný výčet aktivit tohoto „,nestora“ práva sociálního zabezpečení v ČR, jež jsou více či méně vykresleny v prezentované knize. 
Publikace pokrývá periodu oněch 60 let autorova aktivního působení „V oboru“, tj. léta 1955-2015. Počátek tohoto období je spojen s jeho nástupem na místo asistenta na Právnickou fakultu UK. Jakkoli je záměr přiblížit čtenářstvu cíleně profesionální aktivity logický a v souladu s pravdivým ponaučením, že za člověka hovoří především jeho práce, znamená současně i určité ochuzení o formativní léta dětství. To by nemuselo být na škodu, ale za zmínku stojí, že autor, jak sám v úvodu ke knize uvádí, vyrostl střídavě nejen v Brně, ale i Č́ně (Šanghaj), Koreji a Hongkongu. Do dnešní České republiky se vrátil ve věku 15 let. Čtenáře tak může oprávněně napadnout nejen to, jak toto vyrůstání v kulturně odlišném prostředí prožíval, ale zda jej trreba i nějak ovlivnilo v jeho profesním směřování (studium práva) a volbě subdisciplíny (právo sociálního zabezpečení či moderněji a komplexněji sociální právo). To jsou však otázky, které Igor Tomeš ponechává bez odpovědi.

Tematicky kniha pokrývá všechny podstatné etapy autorova života, přesto je patrný důraz zejména na zahraniční expertní činnost pro řadu mezinárodních organizací, vlád, odborných uskupení apod. Z velkého počtu zemí, v nichž pracovně působil, zevrubněji popisuje pobyty v Súdánu, Švýcarsku (Ženeva), Japonsku, SSSR, Albánii, Íránu, Litvě či Gruzii. Zejména z těchto, ale i dalších států, se můžeme dočíst o některých úsměvných i dramatických př́ihodách z cest. Kniha tak má místy blízko až k cestopisu, byt' je velmi precizně strukturovaná a převážně chronologicky členěná.

Troufám si říci, že kniha najde odezvu zejména v řadách odborníků a odbornic z oblasti dějin práva a komparativního práva se zaměřením na právo sociální (pracovní právo a právo sociálního zabezpečení). Konkrétně údaje z doby po listopadu 1989 jsou v kontextu př́ípravy a realizace reformy sociálního zabezpečení velmi poutavé a př́nosné. Do této kategorie bezesporu spadají i zmíněné poznatky ze zavádění sociálních reforem v dalších zemích.

Pro nováčky v oboru může být text nejen představením postavy a aktivit Igora Tomeše, ale také určitou upoutávkou či podnětem pro další studium sociální politiky a práva. Pro znalejší věci bude naopak zdrojem reálií a detailů, které v akademických textech jen tak nenajdeme. Při solitérním čtení pouze tohoto autorova titulu se může čtenáři vkrádat na mysl, že by se chtěl o tom či onom problému dozvědět více, ale to opravdu od tohoto formátu nelze očekávat. Naopak, ponouká-li literatura k chuti dozvědět se více, je to přesně to, k čemu by měla sloužit. At' už tedy kniha bude uvedením do Tomešova profesního působení, či jeho dokreslením, v obou případech jistě zaujme a rozšśŕí obzory.

V průběhu četby si lze současně vytvořit představu o tom, jak Igor Tomeš sociální politiku (právo a správu) patrně pojímal. Nebyly to pro něj zdaleka jen akademické a teoretické disciplíny či konečné výstupy v podobě legislativy a strategických dokumentů (tj. politika ve smyslu anglického policy), nýbrž vnímal dost možná především ,,procesuální“ a ideálně konsensuální charakter jejich vzniku (politika jako politics), a především pak rozměr těchto disciplín jako, ,řemesla“. Jedna věc je proklamovat, co by se „mělo či nemělo“, ale dovednost převést tento záměr do podoby přehledných a srozumitelných pravidel a postupů je věc diametrálně odlišná. A troufám si říci, že právě tato schopnost transformace idejí ve využitelné výstupy dnes často absentuje. Navíc, jak uvádí syn Igora Tomeše stejného jména, jeho otec měl vzácnou schopnost najít řešení schůdné pro všechny zúčastněné. Pracovní nasazení, kreativita, komunikativnost a současně zaměření na cíl byly patrně jeho přednostmi.

Zvláště u literárního žánru „memoárů“ (jakkoli se zde nejedná o „,všeobecné“ paměti, nýbrž ty profesní) platí, že autor je měřítkem všech událostí, které jsou v nich zazname- 
nány. Některé snad proto mohou působit nadbytečně či příliš obsáhle, jiné naopak stručně anebo chybí zcela. To je „riziko“, s nímž je nutné počítat. Avšak v tomto ohledu působí vzpomínky Igora Tomeše poměrně vyváženě. Snad jen některé zeměpisné a historicko-politické detaily z navštívených zemí mohou působit zbytně, byt', jak sám autor uvádí, předpokladem úspěchu odborné práce v zahraničí je detailní znalost prostředí. I to může místo těchto údajů v knize legitimizovat - navíc jsou důkazem autorova rozhledu také v oblasti politické geografie a dějin daných zemí.

Osobně bych uvítal více poznatků a reflexe z dlouholetého pedagogického působení, at' na Právnické fakultě UK, tak na katedře sociální práce Filozofické fakulty UK, kde Igor Tomeš pracoval v letech polistopadových. Tím spíše, že autor toto pracoviště opakovaně označuje jako „naše katedra“. Omezení se na elementární charakteristiku, zhodnocení svého působení a přehled vyučovaných kurzů mi přijde poměrně skromné zaznamenání tak bohaté učitelské práce. Podobně je tomu v př́ípadě psaní odborných monografií. Poměrně dlouho jsme byli odkázáni na autorovu knihu Sociálni politika - teorie a mezinárodní zkušenosti (1996, resp. 2001). Zhruba po roce 2000, a ještě intenzivněji v období po roce 2010, kdy završoval svoje internacionální závazky (zcela je ukončil v roce 2012, dodejme, že v úctyhodném věku 80 let), Igor Tomeš hojně publikoval. Kromě přehledu titulů a letmých zmínek se ale v knize nedozvídáme mnoho o tom, jak vznikaly, jaká úskalí v tomto směru autor musel překonávat, co mu naopak pomáhalo apod. Také tuzemské vědecké a výzkumné aktivity jsou až na výjimky popsány snad až př́liš přehledově.

Pokud jde o formální kvality textu, je patrná citlivá redakční práce. Z předmluvy i poznámky na závěr se lze dozvědět více o provedených úpravách plynoucích z toho, že text byl nalezen in memoriam. Přesto jako ne př́iliš zdařilý nápad hodnotím vypuštění seznamu zkratek, jenž byl v původním rukopisu podle všeho uveden, během přípravy k tisku. Zkratek je užíváno skutečně hojně, a ne všechny jsou dnes běžně používané, už s ohledem na široké a turbulentní časové období, které kniha překlenuje. Je tak občas potřeba listovat či dohledávat jejich význam.

Sám Igor Tomeš píše věcně a srozumitelně, současně ale poutavě a bez patosu či sebelítosti nad lety následujícími po roce 1968, kdy musel nuceně opustit akademickou půdu a železná opona mu znemožnila zahraniční expertní činnost - možnost emigrace s ohledem na př́ípadné důsledky pro svoji rodinu a blízké několikrát odmítl. Svůj život hodnotí (spolu s Nerudou) slovy: „Vším, čím jsem byl, tím jsem byl rád“. A dodává: „protože jsem konal z vlastní svobodné vůle“. Nevyužívá prostor knihy ani k tomu, aby si „,vyřizoval účty“. Naopak je neuvěřitelné, že si při formulování textu vybavoval jména všech svých spolupracovníků za tak dlouhé časové období. Je skoro úsměvné, jak místy, kde si jméno nepamatoval, uvedl až kajícnou poznámku: „Jméno si nepamatuji.“ Dodejme, že je to více než pochopitelné. Otevřeně píše i o svých politických názorech a omezených angažmá v oficiálních strukturách. Přesto se přiznám, že některá zcela ojedinělá hodnocení či výroky mi nepřišly zcela namístě. Ale to je jistě na posouzení a „citu“ každého, komu se kniha dostane do rukou.

Knihu tvoří Tomešovy profesní vzpomínky, je jakousi personalizovanou historií nestora českého práva sociálního zabezpečení. Dozvídáme se snad i proto jen minimum informací z jeho soukromí. Jak trávil volný čas a co rád dělal, se nesvěřuje. U (úspěšných) mužů nebývá zvykem ptát se na rodinné zázemí, ale při četbě jsem si opakovaně ř́kal, jak asi tak časté a mnohdy i delší pracovní cesty zasahovaly do chodu domácnosti a výchovy 
dětí. A jaká byla v tomto směru role manželky Soni, která do určité míry participovala i na odborných aktivitách a opakovaně svého muže na zahraničních cestách „doprovázela“, jak je v knize uvedeno. Jak tedy vypadalo každodenní soužití a prolínání aktivit profesních, rodinných a soukromých, nám text nesděluje. Jistě, není to jeho účelem, přesto se jedná o vzájemně propojené „,nádoby“, jelikož, chce-li se člověk věnovat akademické činnosti, musí k tomu mít kromě potřebných předpokladů a vzdělání také elementární podmínky a čas.

Vydané knižní paměti dokreslují „obraz“ Igora Tomeše nejen jako předního odborníka, ale především člověka, který svoje celoživotní poznatky vtělil do několika vynikajících publikací, jež s úspěchem slouží studujícím i profesionálům sociální politiky, sociálního práva, sociální práce a dalších oborů. Ani tento ,portrét“ však není kompletní, neukazuje jej zcela jako osobu ,soukromou“, ale v první řadě zaníceně pracující a poznávající. Pokud lze jeho ostatní knihy označit jako „hmotu“, pak tato kniha je jejich zdařilým „procesním“ protějškem, jenž ukazuje, jak se dělá sociální politika a právo.

Igor Tomeš byl - podle slov osob, které knihu doplnily o svoje poznámky -, optimista, který hleděl kupředu. Jak píše ve svých pamětech, naučila ho tomu zkušenost let válečných. A tak dovolte, abych skončil jeho slovy, která tento přístup vyjadřují. Doufejme, že již nikdy nebudeme v situaci, jakou byla druhá světová válka. Přesto i za okolností osobních nezdarů a třeba i proher je možné najít v nich inspiraci. „Když prohraješ, nepočítej ztráty, ale to, co ti zbylo, a mysli na budoucnost, koukej dopředu, ne dozadu. Neoplakávej minulost. Z minulosti se jen pouč pro budoucnost, abys neopakoval chyby.“

Josef Vošmik 1

doi: $10.14712 / 2464689 X .2020 .42$

1 Autor recenze působí na Fakultě humanitních studií Univerzity Karlovy. 